\title{
Production, purification and characterization of a thermotolerant alkaline serine protease from a novel species Bacillus caseinilyticus
}

\author{
Thirumala Mothe ${ }^{1} \cdot$ Vishnuvardhan Reddy Sultanpuram $^{1}$
}

Received: 12 June 2015/ Accepted: 3 October 2015/Published online: 13 February 2016

(C) The Author(s) 2016. This article is published with open access at Springerlink.com

\begin{abstract}
Alkaline proteases are important enzymes in many industrial applications, especially as additives in laundry detergent industry. Though there are a number of Bacillus species which are reported to be producing proteases, the efficiency of a protease produced by a novel strain has to be studied in comparison to the others. Hence, in this study, an alkaline serine protease produced by a novel species Bacillus caseinilyticus was purified and characterized for its possible usage in detergent industry. Ammonium sulphate, dialysis and DEAE column chromatographic methods were used for purification of the isolated alkaline protease. The molecular weight of the protease was determined by SDS-PAGE and it was found to be $66 \mathrm{kDa}$. Peptide mass fingerprinting (PMF) was carried out using MALDI-TOF-TOF mass spectrometry and the peptides were found to be similar to that of subtilisin protease. Specific activity of purified protein was found to be $89.2 \mathrm{U} / \mathrm{mg}$. Optimum $\mathrm{pH}$ and temperature for enzyme activity were at $\mathrm{pH} 8$ and $60^{\circ} \mathrm{C}$, respectively, showing stability with $10 \mathrm{mM} \mathrm{CaCl}{ }_{2}$. Phenyl methyl sulphonyl fluoride (PMSF) at both 5 and $10 \mathrm{mM}$ concentrations completely inhibited the enzyme activity suggesting its serine nature. EDTA, metal ions $\mathrm{Mg}^{2+}$ and $\mathrm{Ca}^{2+}$ increased the enzyme activity. The one factor at a time optimisation of the protease production was carried to identify the important factors that affect its production. After optimisation, the protease was produced at lab scale, purified and characterised. This alkali, thermotolerant
\end{abstract}

Vishnuvardhan Reddy Sultanpuram

vishnu_micro@yahoo.co.in

1 Microbial Ecology Lab, Department of Biochemistry, Mahatma Gandhi University, Anneparthy, Yellareddygudem (PO), Nalgonda 508254, Telangana, India serine protease was found to be significantly stable in the presence of various surfactants and $\mathrm{H}_{2} \mathrm{O}_{2}$. Also, it was successfully able to remove blood stain when used as an additive along with commercial detergent suggesting its potential application in the laundry detergent industry.

Keywords Protease - Assay · Application · Laundry detergent industry

\section{Introduction}

Nearly two-third of commercial proteases are produced by fungal species, yeasts and bacteria (Wang et al. 2013). Proteases have diverse applications in various industries, such as, food, pharmaceuticals, silk and diagnostics with predominant use in detergent and leather industries (Banik and Prakash 2004; Gupta et al. 2002). The demand for industrial enzymes, particularly of microbial origin, is ever increasing owing to their applications in wide variety of processes. Proteases represent one of the three largest groups of industrial enzymes and account for about $60 \%$ of the total worldwide sale of the enzymes (Rajkumar et al. 2011).

Proteases are broadly classified as endo or exoenzymes on the basis of their site of action on protein substrates. They are further categorized as serine proteases, aspartic proteases, cysteine proteases or metalloproteases depending on their catalytic mechanism (Geethanjali and Subash 2011). Alkaline serine proteases of microbial origin possess considerable industrial potential due to their biochemical diversity and wide applications in tannery, food industries, medicinal formulations, detergents and processes like waste treatment, silver recovery and resolution of amino acid mixtures (Agarwal et al. 2004). 
Bacillus species are specific producers of extracellular protease. Several alkaline proteases have been purified and characterized from many Bacillus strains (Rao et al. 1998). Subtilisin Carlsberg produced by Bacillus liceniformis (Jacobs et al. 1985) and Subtilisin Novo produced by Bacillus amyloliquefaciens (Wells et al. 1983) have been the enzymes of choice for detergent industries. These enzymes exhibit maximum activity at alkaline $\mathrm{pH}$ values ranging from 8 to 10 (Horikoshi 1999). Generally the alkaline proteases for detergent applications should be active at temperature higher than $40-50{ }^{\circ} \mathrm{C}$ and $\mathrm{pH}$ in the range of 9-12 (Sellami-Kamoun et al. 2008; Hadder et al. 2009).

The purification process also increases the specific activities of enzymes, making them more specific for industrial applications. In the present study, we report purification and characterization of a thermotolerant alkaline serine protease produced by a novel species, Bacillus caseinilyticus.

\section{Materials and methods}

\section{Materials}

Bovine Serum Albumin (BSA), reagents for protein estimation and SDS-PAGE, DEAE-Cellulose were purchased from Hi-Media, Mumbai, India. Silica gel TLC plates $(0.25 \mathrm{~mm})$, trichloroacetic acid (TCA), casein and other analytical grade chemicals were purchased from Merck, Mumbai, India.

\section{Microorganism}

A novel Bacillus strain $\mathrm{SP}^{\mathrm{T}}$ was isolated from the alkaline Lonar Lake, located at Buldhana, Maharashtra, India. The detailed taxonomic characterisation and identification of this strain proposed as a novel species, Bacillus caseinilyticus has been described elsewhere (Vishnuvardhan Reddy et al. 2015).

\section{Optimization of culture conditions and media for protease production: one-factor-at-a time}

Production of protease by Bacillus caseinilyticus was carried out in basal medium with the following composition $\left(\mathrm{g} \mathrm{l}^{-1}\right)$ : yeast extract, $0.01 ; \mathrm{KH}_{2} \mathrm{PO}_{4}, 0.5 ; \mathrm{MgSO}_{4} \cdot 7 \mathrm{H}_{2} \mathrm{O}$, $0.2 ;\left(\mathrm{NH}_{4}\right)_{2} \mathrm{HPO}_{4}, 1.0 ; \mathrm{NaCl}, 60$ with different combinations of carbon and nitrogen substrates $(1 \% \mathrm{w} / \mathrm{v})$ and $1 \%$ inoculum size at $37^{\circ} \mathrm{C}$ for $48 \mathrm{~h}$ in a rotary shaker (180 rpm). The initial $\mathrm{pH}$ of the medium was adjusted to 8.0. Parametric optimization was performed with respect to substrates (both carbon and nitrogen), metal ions, $\mathrm{pH}$, temperature, fermentation period and their individual effects were monitored. The cell-free supernatant was recovered by centrifugation at $10,000 \mathrm{rpm}$ for $10 \mathrm{~min}$ at $4{ }^{\circ} \mathrm{C}$ and used for determining extracellular protease activity.

For screening significant variables affecting protease production by Bacillus caseinilyticus, various carbon (1\% $\mathrm{w} / \mathrm{v}$; glucose, sucrose, lactose, fructose and maltose), nitrogen ( $1 \% \mathrm{w} / \mathrm{v}$; ammonium chloride, malt extract, yeast extract, peptone and skim milk) substrates, metal chlorides $\left(\mathrm{CaCl}_{2}, \mathrm{MgCl}_{2}, \mathrm{ZnCl}_{2}, \mathrm{FeCl}_{2}\right.$ and $\left.\mathrm{CuCl}_{2}\right)$ at $5 \mathrm{mM}$ concentration, incubation time $(24,48,74,98$ and $120 \mathrm{~h})$, temperature $\left(20,30,37,40,50,60\right.$ and $\left.70{ }^{\circ} \mathrm{C}\right)$ and $\mathrm{pH}(6,7$, $8,9,10,10.5$ and 12) were tested by one-factor-at-a time strategy. Controls were prepared simultaneously to compare the data of tests without adding any carbon, nitrogen sources or metal chlorides.

\section{Enzyme assay}

Alkaline protease activity was determined with the method of Lin et al. (1969) using $N, N$-dimethylated casein (DMC) as a substrate. The reaction mixture containing $2 \mathrm{ml}$ of $1 \%$ (w/v) DMC in $100 \mathrm{mM}$ borate-hydrochloride buffer $(\mathrm{pH}$ 8), $0.25 \mathrm{ml}$ of $1 \%$ 2,4,6-trinitrobenzene sulfonic acid (as a colour indicator) and $1 \mathrm{ml}$ of cell free extract with enzyme was incubated at $60{ }^{\circ} \mathrm{C}$ for $25 \mathrm{~min}$ with constant shaking. After incubation the reaction was stopped by adding $2.5 \mathrm{ml}$ cold water for $15 \mathrm{~min}$. The precipitate was then removed by centrifugation at $10,000 \times g$ for $15 \mathrm{~min}$ at $4{ }^{\circ} \mathrm{C}$ and absorbance was measured at $450 \mathrm{~nm}$ against blank. The amount of the enzyme which catalysed the cleavage of $1 \mu \mathrm{mol}$ of peptide bond from DMC per minute under the experimental conditions used was defined as one proteolytic unit (IU).

\section{Protein estimation}

Total protein content was determined by Lowry et al. (1951) using bovine serum albumin as reference.

\section{Protease purification}

\section{Ammonium sulphate precipitation}

Ammonium sulphate precipitation was the method by which cell free supernatant was precipitated using different saturation levels of ammonium sulphate (40, 50, 60, 70 and $80 \%$ ). After each addition, the enzyme solution was stirred for $1 \mathrm{~h}$ at $4{ }^{\circ} \mathrm{C}$. The precipitated protein was separated by centrifugation at $12,000 \times g$ for $20 \mathrm{~min}$ at $4{ }^{\circ} \mathrm{C}$ and resuspended in small volume of $0.05 \mathrm{M}$ Tris- $\mathrm{HCl}$ buffer, $\mathrm{pH} 8.0$ to get the concentrated enzyme suspension. The precipitate 
was harvested by centrifugation at $10,000 \times g$ for $15 \mathrm{~min}$, than dissolved in $20 \mathrm{mM}$ Tris- $\mathrm{HCl}$ buffer $(\mathrm{pH} \mathrm{8.8)}$ and dialysed against the same buffer overnight at $4{ }^{\circ} \mathrm{C}$.

\section{Purification of protease by DEAE cellulose column chromatography}

Further purification was carried out using DEAE cellulose column chromatography, for which $100 \mathrm{ml}$ dialysed enzyme was applied to DEAE-cellulose column $(2.4 \times 45 \mathrm{~cm})$ pre-equilibrated with $0.05 \mathrm{M}$ Tris- $\mathrm{HCl}$ buffer ( $\mathrm{pH} 8)$. The enzyme was eluted with the same buffer at a flow rate of $20 \mathrm{ml} / \mathrm{h}$.

\section{SDS-polyacrylamide gel electrophoresis and peptide mass spectrometry}

The molecular weight of the alkaline protease was determined by running the SDS-PAGE against standard molecular weight protein marker including phosphorylase $\mathrm{b}$ $(97.4 \mathrm{kDa})$, bovine serum albumin $(66 \mathrm{kDa})$, egg ovalbumin $(45 \mathrm{kDa})$, and carbonic anhydrase $(29 \mathrm{kDa})$ and analysing after band formation (Laemmli 1970). The gels were stained with Coomassie Brilliant Blue R-250 in methanolacetic acid-water (5:1:5, v/v), and decolorized with $7 \%$ acetic acid. Further, the molecular mass of the peptides of the purified protein were analyzed by the method of matrix assisted laser desorption ionization-time of flight-time of flight (MALDI-TOF-TOF) mass spectrometry. The instrumentation used was the Applied Biosystems (AB) Model 4800 MALDI-TOF/TOF mass spectrometer. Reflectron MS analysis sums 1250 laser shots to generate the peptide fingerprint map (PFM) and the spectra were internally calibrated using the bradykinin as an internal standard. Masses were chosen by the $A B 4000$ Series Explorer software (version 3.0) for MS/MS acquisition.

\section{Effect of $\mathrm{pH}$ and temperature on enzyme activity and stability}

To determine the effect of $\mathrm{pH}$ and temperature on protease activity, the reaction mixtures [diluted enzyme (10 $\mu \mathrm{l}$ of purified enzyme $+190 \mu \mathrm{l}$ buffer $)+1 \%$ (w/v) DMC as a substrate] were incubated at different $\mathrm{pH}$ values $(6-12)$ and temperatures $\left(30-100{ }^{\circ} \mathrm{C}\right)$. The different buffers used were: (0.05 M) phosphate ( $\mathrm{pH}$ 6-7), Tris- $\mathrm{HCl}(\mathrm{pH} 8-9)$ and glycine- $\mathrm{NaOH}(\mathrm{pH} 10-12)$. To check the $\mathrm{pH}$ stability $10 \mu \mathrm{l}$ of enzyme and $190 \mu \mathrm{l}$ of the above said buffer solutions were incubated. The residual activities were then measured according to the standard assay method. To determine the stability, the enzyme was preincubated for $24 \mathrm{~h}$ at the above mentioned reaction conditions with $5 \mathrm{mM}$ and $10 \mathrm{mM} \mathrm{CaCl}_{2}$.

\section{Concentration determination by active site titration}

The active site titration was performed using $p$-nitrophenyl $p^{\prime}$-guanidinobenzoate (PNPGB). A $10 \mathrm{mM}$ PNPGB stock solution in dimethyl formamide (DMF) was prepared. To $990 \mu \mathrm{L}$ purified enzyme solution, $10 \mu \mathrm{L} 10 \mathrm{mM}$ PNPGB was added, mixed quickly and thoroughly and OD was measured immediately at $410 \mathrm{~nm}$ (Chase and Shaw 1969).

\section{Effect of inhibitors and metal ions on protease activity}

Effect of various inhibitors, such as, PMSF (phenyl methyl sulphonyl fluoride) at $5 \mathrm{mM}$ and $10 \mathrm{mM}$ concentrations, ethylene diamine tetra acetic acid (EDTA) and metal ions $\left(\mathrm{Ca}^{2+}, \mathrm{Mg}^{2+}, \mathrm{Zn}^{2+}, \mathrm{Co}^{2+}, \mathrm{Fe}^{2+}, \mathrm{Na}^{2+}, \mathrm{Cu}^{2+}\right.$ and $\left.\mathrm{Ni}^{2+}\right)$ at $5 \mathrm{mM}$ concentrations on protease activity were studied. The purified enzyme was preincubated with the above mentioned inhibitors and metal ions $(10 \mu \mathrm{l}$ enzy$\mathrm{me}+190 \mu \mathrm{l} 500 \mathrm{mM}$ Tris- $\mathrm{HCl}$ buffer and $1 \%$ (w/v) DMC as substrate) for $1 \mathrm{~h}$ at $60{ }^{\circ} \mathrm{C}$ and then assayed for residual activity. Controls were also run without inhibitors and metal ions along with tests.

\section{Effect of different substrates on enzyme activity}

The effect of different substrates on the alkaline protease was checked using various substrates like, casein, gelatin, bovine serum albumin (BSA) and egg albumin. The reaction mixture containing $200 \mu \mathrm{l}$ of enzyme and $200 \mu \mathrm{l}$ of substrate $(1 \mathrm{mg} / \mathrm{ml})$ was incubated at $60^{\circ} \mathrm{C}$ for $20 \mathrm{~min}$ and the activity was estimated using standard assay.

\section{Effect of polar and non-polar solvents on protease activity}

The effect of solvents on enzyme activity was studied by incubating the enzyme with $(10 \mu \mathrm{l}$ enzyme $+190 \mu \mathrm{l}$ $500 \mathrm{mM}$ Tris- $\mathrm{HCl}$ buffer and $1 \%$ (w/v) DMC as substrate) the polar and non-polar solvents $(10 \% \mathrm{v} / \mathrm{v})$, such as, acetone, benzene, chloroform, hexane and toluene for $24 \mathrm{~h}$ at $60{ }^{\circ} \mathrm{C}$ and than assayed for residual activity of the enzyme. Controls were run along with the tests.

\section{Effect of surfactants and different oxidizing agents on stability of protease}

Effect of Tween 20 at $0.5 \%, 1 \%$, SDS at $0.5 \%, 1 \%$ and $\mathrm{H}_{2} \mathrm{O}_{2}$ at $0.5 \%$ and $1 \%$ were studied on protease activity by incubating the mixtures $(10 \mu \mathrm{l}$ enzyme $+190 \mu \mathrm{l}$ $500 \mathrm{mM}$ Tris- $\mathrm{HCl}$ buffer and $1 \%$ (w/v) DMC as substrate) for $1 \mathrm{~h}$ at $60{ }^{\circ} \mathrm{C}$. Later the residual activities were measured; controls were used in studies without surfactants and oxidizing agent. 


\section{Statistical analysis}

All the experiments were performed in triplicate each time. The mean \pm standard deviation (SD) and Spearman's rank correlation coefficient was employed on the data for protease production, protease activity and stability at different temperatures and $\mathrm{pH}$ concentrations were tested for their significance using Microsoft Excel.

\section{Application of purified protease on blood stain removal}

Application of the purified protease as a detergent additive in blood stain removal was studied on white cotton cloth pieces $(10 \mathrm{~cm} \times 10 \mathrm{~cm})$ stained with blood and oven dried at $95-100{ }^{\circ} \mathrm{C}$ for $5 \mathrm{~min}$. The stained cloth pieces were taken in separate trays. The following sets were prepared and studied:

(a) Tray with distilled water $(100 \mathrm{ml})+$ blood stained cloth $+1 \mathrm{ml}$ of commercial detergent (Surf excel$5 \mathrm{mg} / \mathrm{ml})+2 \mathrm{ml}$ of purified enzyme.

(b) Tray with distilled water $(100 \mathrm{ml})+$ blood stained cloth $+1 \mathrm{ml}$ of commercial detergent (Surf excel$5 \mathrm{mg} / \mathrm{ml}$ ).

(c) Untreated cloth piece stained with blood was considered as control.

(d) Tray with distilled water $(100 \mathrm{ml})+$ blood stained cloth $+2 \mathrm{ml}$ of purified enzyme.

(e) Tray with distilled water $(100 \mathrm{ml})+$ blood stained cloth.

The trays were incubated at $50{ }^{\circ} \mathrm{C}$ for $30 \mathrm{~min}$. The cloth pieces were taken out from each set at regular intervals of 5 min, rinsed with water, dried and visually examined.

\section{Results and discussion}

\section{Optimization of culture conditions and media for protease production: one-factor-at-a time}

The organism was able to produce protease at a $\mathrm{pH}$ range of 7.0-10.0 (optimum production at $\mathrm{pH} 9.0$ ) and at a temperature range of $30-60{ }^{\circ} \mathrm{C}$ (optimum production at $37^{\circ} \mathrm{C}$ ). Among the carbon sources tested, fructose showed more production ability, followed by sucrose. Among different organic nitrogen sources, skim milk gave maximum protease yield followed by malt extract, peptone and yeast extract. Ammonium chloride as inorganic nitrogen source was found to inhibit the production. $\mathrm{MgCl}_{2}$ and $\mathrm{CaCl}_{2}$ induced protease production, whereas, other metal salts like $\mathrm{ZnCl}_{2}, \mathrm{FeCl}_{2}$ and $\mathrm{CuCl}_{2}$ had minimal effect. Increase in incubation time enhanced protease production till $48 \mathrm{~h}$.
But, gradual decrease in enzyme production was observed with prolongation of fermentation time (Table 1).

The optimized parameters were used for the production of the enzyme in the medium with fructose as the carbon source and skim milk powder as the nitrogen source, with $\mathrm{MgCl}_{2}$ and $\mathrm{CaCl}_{2}$ as additional additives. The final $\mathrm{pH}$ of the medium was adjusted to 9.0 and the organism was grown at $37^{\circ} \mathrm{C}$ for $48 \mathrm{~h}$.

\section{Purification and mass peptide spectroscopy of alkaline protease}

After production of enzyme, it was precipitated optimally using ammonium sulphate at $60 \%$ saturation level. The ammonium sulphate saturation increased the protein purification 1.65 fold with $60 \%$ recovery; later on enzyme was purified by dialysis method. The dialysed sample was further purified by DEAE cellulose column chromatography. The purification of protein using the DEAE cellulose column chromatography increased the purity of the protein by 20.74 -fold compared to ammonium sulphate precipitation and dialysis (Table 2). Specific activity of purified protein was $89.2 \mathrm{U} / \mathrm{mg}$. Enzyme purity was confirmed by SDS-PAGE with the help of standard protein marker run against the test sample. The molecular weight of the protein was found to be $66 \mathrm{kDa}$ (Fig. 1). A $34 \mathrm{kDa}$ serine protease from $B$. pumilus $\mathrm{CBS}$, and a $35 \mathrm{kDa}$ manganesedependent alkaline serine protease from $B$. pumilus TMS55 have been previously reported (Jaouadi et al. 2008; Ibrahim et al. 2011). Moreover, a $38 \mathrm{kDa}$ organic solvent and detergent stable protease was also reported from Bacillus sp. RKY3 (Reddy et al. 2008). The molecular weight of the isolated enzyme was in the range of some reported Bacillus proteases.

The peptide mass fingerprinting (PMF) of the protein after digestion with trypsin yielded eight prominent $\mathrm{m} /$ $z$ peaks (Fig. 2). The $\mathrm{m} / \mathrm{z}$ values corresponding at 1958.2, 1324.6 and 1308.9 were identified as peptides with sequences LEAAPVMFPERPAYPDR, GVAPDAEIYAYR and LIGETIADFSSR, respectively. These peptides were similar to peptidase S8 and S53 subtilisin from Bacillus cellulosilyticus.

\section{Effect of $\mathrm{pH}$ and temperature on alkaline protease activity and stability}

The enzyme exhibited activity in the wide range of $\mathrm{pH}$ from 6 to 10 with the maximum activity at $\mathrm{pH} 8(P \leq 0.1)$, which supports that the enzyme with alkaline nature. Some of the Bacillus derived proteases viz. from B. subtilis NCIM 2713 reported by Mane and Bapat, had an optimum activity at $\mathrm{pH} 8$ and was stable at $\mathrm{pH}$ 6.5-9 (Mane and Bapat 2001). The protease from $B$. subtilis VSG-4 reported 
Table 1 Effect of fermentation period, $\mathrm{pH}$, temperature, carbon sources, nitrogen sources and metal chlorides on alkaline serine protease production by Bacillus caseinilyticus

\begin{tabular}{|c|c|}
\hline Fermentation period (h) & $\begin{array}{l}\text { Protein concentration } \\
(\mathrm{mg} / \mathrm{ml})\end{array}$ \\
\hline 26 & $39.30 \pm 2.5$ \\
\hline 48 & $42.67 \pm 3.5$ \\
\hline 74 & $34.65 \pm 4.0$ \\
\hline 98 & $28.76 \pm 2.8$ \\
\hline 120 & $24.35 \pm 2.1$ \\
\hline \multicolumn{2}{|l|}{$\mathrm{pH}$} \\
\hline 6 & 0 \\
\hline 7 & $29.30 \pm 3.5$ \\
\hline 8 & $33.67 \pm 2.5$ \\
\hline 9 & $49.76 \pm 1.5$ \\
\hline 10 & $28.16 \pm 2.6$ \\
\hline 10.5 & 0 \\
\hline 12 & 0 \\
\hline \multicolumn{2}{|l|}{ Temperature $\left({ }^{\circ} \mathrm{C}\right)$} \\
\hline 20 & 0 \\
\hline 30 & $39.10 \pm 2.5$ \\
\hline 37 & $49.99 \pm 3.5$ \\
\hline 40 & $39.76 \pm 1.5$ \\
\hline 50 & $28.16 \pm 2.9$ \\
\hline 60 & $20.22 \pm 1.8$ \\
\hline 70 & 0 \\
\hline \multicolumn{2}{|l|}{ Carbon sources } \\
\hline Glucose & $33.55 \pm 1.9$ \\
\hline Sucrose & $42.66 \pm 1.8$ \\
\hline Lactose & $39.16 \pm 1.8$ \\
\hline Fructose & $48.16 \pm 1.9$ \\
\hline Maltose & $21.92 \pm 1.7$ \\
\hline \multicolumn{2}{|l|}{ Nitrogen sources } \\
\hline Ammonium chloride & 0 \\
\hline Malt extract & $43.99 \pm 1.9$ \\
\hline Yeast extract & $31.19 \pm 1.2$ \\
\hline Peptone & $39.19 \pm 1.0$ \\
\hline Skim milk & $47.92 \pm 2.1$ \\
\hline \multicolumn{2}{|l|}{ Metal chlorides } \\
\hline $\mathrm{CaCl}_{2}$ & $42.35 \pm 2.1$ \\
\hline $\mathrm{MgCl}_{2}$ & $42.55 \pm 3.9$ \\
\hline $\mathrm{ZnCl}_{2}$ & $39.77 \pm 2.8$ \\
\hline $\mathrm{FeCl}_{2}$ & $38.68 \pm 2.9$ \\
\hline $\mathrm{CuCl}_{2}$ & $31.29 \pm 1.8$ \\
\hline Control (only basal medium) & $12.45 \pm 3.7$ \\
\hline
\end{tabular}

All the results were presented as mean \pm SD

by Giri et al. (2011) had the maximum activity at $\mathrm{pH} 9$ with a sharp decline in the activity in $\mathrm{pH}$ values lower than $\mathrm{pH}$ 9. An extracellular hrtA-like serine protease by B. subtilis DR8806 exhibited high activity in the range of $\mathrm{pH}$ from 5 to 10 with the maximum activity at $\mathrm{pH} 8$ (Farhadian et al. 2015). Similarly, a halophilic bacterium isolated from sea water catalyzed reactions in the $\mathrm{pH}$ range 8-11 and performed optimally at pH 10 (Raval et al. 2014). Enzyme isolated in this study was more stable at $\mathrm{pH} 8$ in presence of $10 \mathrm{mM} \mathrm{CaCl}_{2}$ (Fig. 3).

Effect of different temperatures showed that the enzyme was active at these varied temperatures, however, optimum temperature was found to be $60{ }^{\circ} \mathrm{C}(P \leq 0.1)$ supporting thermotolerant nature of the enzyme. Maximum proteolytic activity of Bacillus strains HR-08 and KR-8102 isolated from soil of western and northern parts of Iran have been recorded at 65 and $50{ }^{\circ} \mathrm{C}$, respectively (Moradian et al. 2006). A serine protease by B. subtilis DR8806 showed highest activity at $45^{\circ} \mathrm{C}$ and withstood at temperature up to $70{ }^{\circ} \mathrm{C}$ (Farhadian et al. 2015). Cha et al. (2005) reported that the protease from Bacillus sp. SS103 was active at $37{ }^{\circ} \mathrm{C}$ and the alkaline protease from B.subtilis VSG-4 that previously reported by Giri et al. (2011) was active over a range of temperature from 40 to $60{ }^{\circ} \mathrm{C}$ with an optimum temperature at $50{ }^{\circ} \mathrm{C}$. In addition, Huang et al. purified an alkaline protease that had maximum activity at $55^{\circ} \mathrm{C}$ (Huang et al. 2003).

In the present study, enzyme activity gradually increased from temperature $30-60{ }^{\circ} \mathrm{C}$, but, after $60{ }^{\circ} \mathrm{C}$, it showed decrease in activity. However, the presence of $10 \mathrm{mM} \mathrm{CaCl}{ }_{2}$ decreased it activity to some extent. Enzyme retained around $98 \%$ residual enzyme activities at $60{ }^{\circ} \mathrm{C}$ in the presence of $10 \mathrm{mM} \mathrm{CaCl}_{2}(P \leq 0.1)$ (Fig. 4).

The active site titration of the enzyme with PNPGB determined the concentration of the enzyme to be $15.0 \mu \mathrm{m}$ (based on OD measured), with $40 \%$ active sites.

\section{Effect of inhibitors and metal ions on enzyme activity}

The tested alkaline protease was almost undisturbed in the presence of EDTA showing an increased relative activity of $96 \%$, and least activity $(30 \%)$ in the presence of $\mathrm{Na}^{2+}$. The results (Table 3) also showed that the enzyme was completely inhibited by serine protease inhibitor (PMSF) at both 5 and $10 \mathrm{mM}$ concentrations, suggesting its serine nature (Adinarayana et al. 2003). Among the metal ions checked on the enzyme activity, $\mathrm{Ca}^{2+}$ and $\mathrm{Mg}^{2+}$ ions increased relative activity up to 82 and $85 \%$ respectively. A serine protease from Bacillus subtilis DR8806 was stimulated by $\mathrm{K}^{+}, \mathrm{Ca}^{2+}, \mathrm{Mg}^{2+}$ and $\mathrm{Fe}^{2+}$ at $10 \mathrm{mM}$ concentration up to $134,129,128$ and $112 \%$, respectively. Whereas, $\mathrm{Na}^{+}$ions had no significant effect on enzyme activity (Farhadian et al. 2015). Metal-decreasing activity in the presence of $\mathrm{Co}^{2+}, \mathrm{Ni}^{2+}$ was observed by Farhadian et al. (2015), Shah et al. (2010), Priya et al. (2014), Ibrahim et al. (2011) and Jain et al. (2012). In contrast, our results 
Table 2 Summary of purification of alkaline serine protease produced by Bacillus caseinilyticus

\begin{tabular}{|c|c|c|c|c|c|}
\hline Purification method & $\begin{array}{l}\text { Total activity } \\
\text { (U) }\end{array}$ & $\begin{array}{l}\text { Total protein } \\
(\mathrm{mg} / \mathrm{ml})\end{array}$ & $\begin{array}{l}\text { Specific activity } \\
(\mathrm{U} / \mathrm{mg})\end{array}$ & $\begin{array}{l}\text { Purification } \\
\text { fold }\end{array}$ & $\begin{array}{l}\text { Yield } \\
(\%)\end{array}$ \\
\hline Crude enzyme & 5.93 & 1.38 & 4.3 & 1.00 & 100 \\
\hline Ammomium sulphate precipitation & 8.52 & 1.20 & 7.1 & 1.65 & 48 \\
\hline Dialysis & 9.60 & 1.00 & 9.6 & 2.23 & 35 \\
\hline DEAE cellulose column chromatography & 11.59 & 0.13 & 89.2 & 20.74 & 18 \\
\hline
\end{tabular}

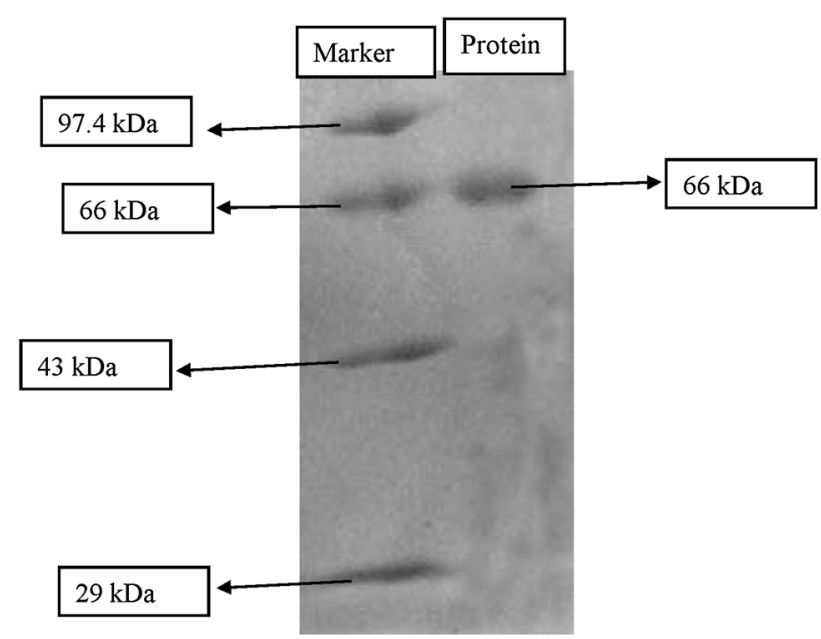

Fig. 1 SDS PAGE of the purified alkaline serine protease of Bacillus caseinilyticus

showed a moderate activity in presence $\mathrm{Zn}^{2+}, \mathrm{Co}^{2+}$ and $\mathrm{Ni}^{2+}$ ions. The enzyme from this study showed less activity in the presence of $\mathrm{Fe}^{2+}$ and $\mathrm{Cu}^{2+}$ ions.

\section{Effect of different substrates on enzymatic activity}

Various substrates were tested to study the activity of alkaline protease. Among casein, bovine serum albumin, gelatin and egg albumin, protease showed high activity (94\%) on casein (Table 3). However, the enzyme could hydrolyze several other proteins like BSA, gelatin and egg albumin, which is an important characteristic of this alkaline protease. Adinarayana et al. (2003) reported similar finding that casein was a good substrate for protease produced by B. subtilis. Our result was in consistent with finding of Dubey et al. (2006) which showed casein was the most preferable substrate. They had shown the activity in the presence of wheat gluten was just $20 \%$, in comparison with casein. Furthermore, proteases produced by $B$. halodurans 373 CAS6 (Annamalai et al. 2013), B. cereus TKU006 (Wang et al. 2009) and B. subtilis DR8806 (Farhadian et al. 2015) showed the most activity towards casein as a substrate.

\section{Effect of polar and non polar solvents on enzymatic activity}

The effect of different organic solvents on stability revealed that the enzyme activity had no effect with hexane $(99.7 \%)$, whereas, moderate effect was found with acetone $(90.9 \%)$, benzene $(95.8 \%)$, and toluene $(89.6 \%)$; whereas, chloroform lowered $(69.8 \%)$ the alkaline protease activity (Table 3 ). Similarly alkaline protease produced by marine bacterium $B$. firmus CAS 7 was quite stable in the presence of anionic and non-ionic surfactants and organic solvents (Neelamegam et al. 2014). Hexane, toluene and butanol at $10 \%(\mathrm{v} / \mathrm{v})$ led to decrease the activity and the presence of DMSO in contrast increase the serine protease by $B$. subtilis DR8806. In contrast, ethanol and methanol at all tested concentrations strongly enhanced the enzyme activity as compared to the control (Farhadian et al. 2015). Jain et al. (2012) showed the protease was activated with solvents, such as, DMSO and hexane. In addition, Rai and Mukheerje demonstrated subtilisin-like serine protease isolated from B. subtilis DM04 increased its activity with hexane, methanol and ethanol (Rai and Mukherjee 2010). A protease from B. pumilus $115 \mathrm{~b}$ has been inactivated by toluene and benzene (Rahman et al. 2007).

\section{Effect of different surfactants and oxidizing agent on activity of alkaline protease}

A good detergent protease must be compatible and stable with all commonly used detergent compounds, such as, surfactants, bleaches, oxidizing agents and other additives which might be present in the formulation (Gupta et al. 2005). Hence different surfactants and oxidizing agent in different concentrations were tested for their effect on the alkaline protease activity. Among the tested (Tween 20, SDS and $\mathrm{H}_{2} \mathrm{O}_{2}$ ), $\mathrm{H}_{2} \mathrm{O}_{2}$ was showing very less effect on the activity of alkaline protease showing a relative activity of up to 91 and $86 \%$ after treatment with 0.5 and $1 \% \mathrm{H}_{2} \mathrm{O}_{2}$, respectively (Table 4). In a similar report, Joo et al. (2003) reported that Bacillus clausii 1-52 protease exhibited relative activity of up to 


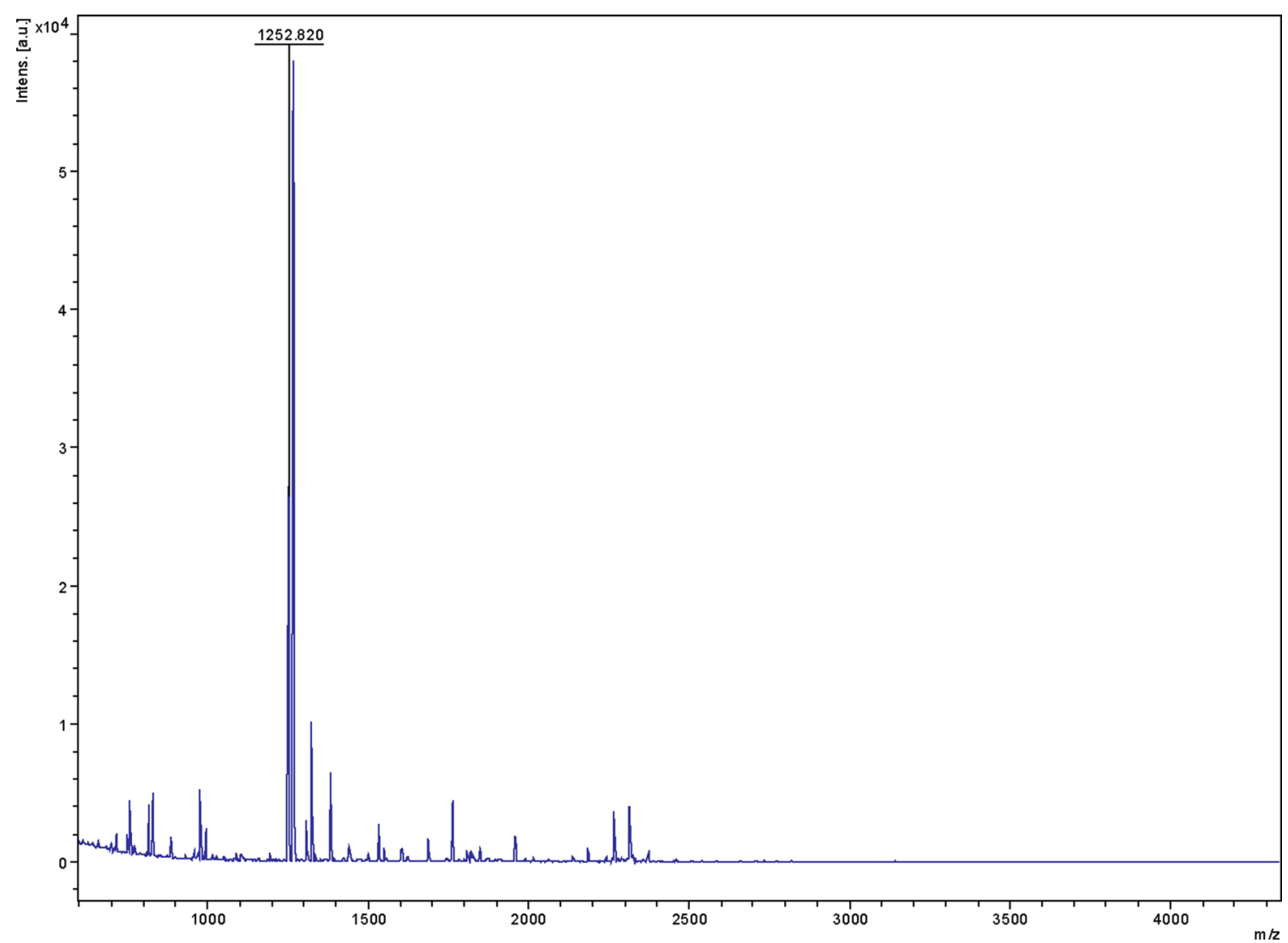

Fig. 2 PFM spectra of alkaline serine protease from Bacillus caseinilyticus

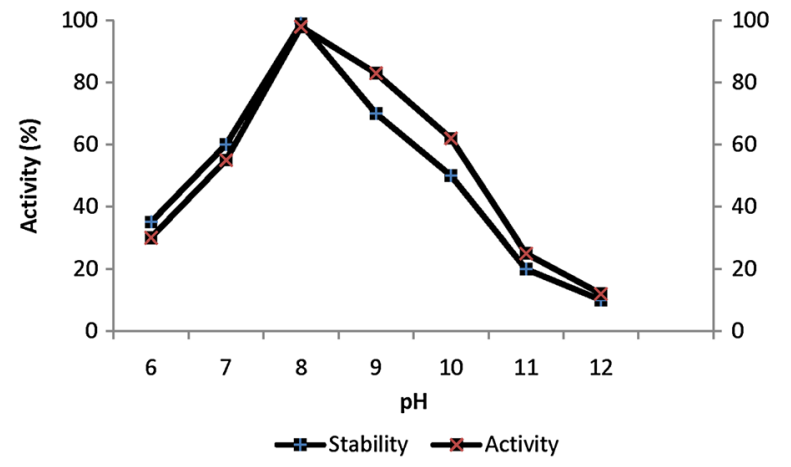

Fig. 3 Effect of $\mathrm{pH}$ on activity and stability of alkaline serine protease of Bacillus caseinilyticus

$114 \%$ after treatment with $1 \% \mathrm{H}_{2} \mathrm{O}_{2}$. The protease produced from Bacillus alcalophilus TCCC11004 was exhibiting $69.2 \%$ activity in the presence of $1 \% \mathrm{H}_{2} \mathrm{O}_{2}$ (Cheng et al. 2010). Our results showed that SDS might have improved the interaction of enzyme with substrate and this could result in increased relative activity than Tween 20. Cheng et al. (2010) reported that the protease produced from Bacillus alcalophilus TCCC11004 was stable in $0.5 \%$ SDS and retained $70.3 \%$ of its initial activity after $1 \mathrm{~h}$ of incubation.

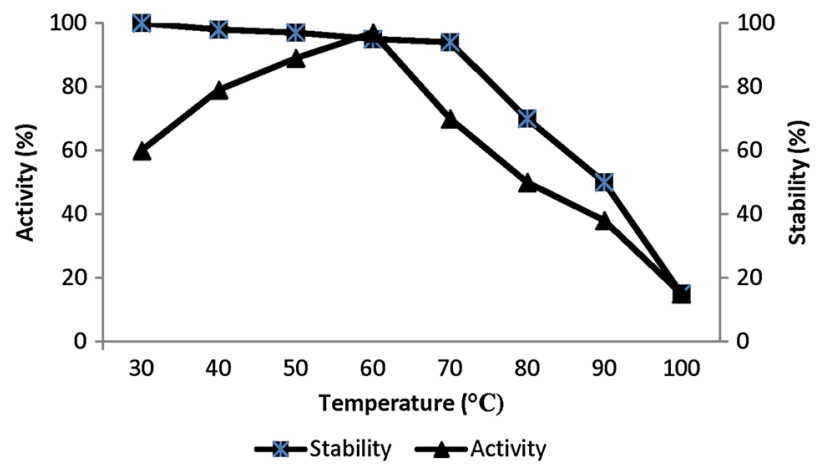

Fig. 4 Effect of temperature on activity and stability of alkaline protease of Bacillus caseinilyticus

\section{Application of purified protease on blood stain removal}

In the blood stain removal experiment, blood stains were removed completely within $30 \mathrm{~min}$ in set A [combination of detergent $(5 \mathrm{mg} / \mathrm{ml})$ and purified enzyme $(2 \mathrm{ml})]$, whereas, blood stains were not removed completely when only the enzyme was used (set D) (Fig. 5). Banerjee et al. (1999) reported that thermostable alkaline protease from Bacillus brevis removed blood stains with combination of 
Table 3 Effect of inhibitors, metal ions $(5 \mathrm{mM})$, substrates $(1 \mathrm{mg}$ / $\mathrm{ml})$ and organic solvents $(10 \%)$ on alkaline protease activity produced by Bacillus caseinilyticus

\begin{tabular}{ll}
\hline Inhibitor/activator & Relative activity $\%$ \\
\hline PMSF & 0 \\
EDTA & $96 \pm 3.9$ \\
$\mathrm{CuCl}_{2}$ & $44 \pm 4.1$ \\
$\mathrm{ZnCl}_{2}$ & $78 \pm 2.1$ \\
$\mathrm{MgCl}_{2}$ & $85 \pm 4.0$ \\
$\mathrm{NaCl}$ & $30 \pm 2.7$ \\
$\mathrm{CaCl}_{2}$ & $82 \pm 3.6$ \\
$\mathrm{FeCl}_{2}$ & $54 \pm 3.9$ \\
$\mathrm{CoCl}_{2}$ & $62 \pm 2.1$ \\
$\mathrm{NiCl}_{2}$ & $58 \pm 4.2$ \\
$\mathrm{Casein}_{\text {Bovine serum albumin }}$ & $94 \pm 2.5$ \\
Gelatin & $40 \pm 4.1$ \\
Egg albumin & $64 \pm 3.7$ \\
Hexane & $85 \pm 2.9$ \\
Acetone & $99.7 \pm 2.6$ \\
Benzene & $90.93 \pm 1.8$ \\
Toulene & $95.8 \pm 2.2$ \\
Chloroform & $89.6 \pm 3.5$ \\
\hline All & $69.8 \pm 3.9$
\end{tabular}

All the results were presented as mean $\pm \mathrm{SD}$

Table 4 Effect of different surfactants and oxidizing agent on stability of alkaline protease produced by Bacillus caseinilyticus

\begin{tabular}{lll}
\hline Surfactants/oxidizing agents & Concentration (\%) & Relative activity \% \\
\hline Tween 20 & 0.5 & $66 \pm 3.9$ \\
& 1.0 & $42 \pm 2.1$ \\
SDS & 0.5 & $81 \pm 2.9$ \\
& 1.0 & $55 \pm 3.5$ \\
$\mathrm{H}_{2} \mathrm{O}_{2}$ & 0.5 & $91 \pm 4.0$ \\
& 1.0 & $86 \pm 2.6$ \\
\hline
\end{tabular}

All the results were presented as mean $\pm \mathrm{SD}$

$7 \mathrm{mg} / \mathrm{ml}$ detergent + enzyme $(2 \mathrm{ml})$ for $25 \mathrm{~min}$ and similarly, in an another report, blood stains were removed completely within $15 \mathrm{~min}$ in combination of detergent $(6 \mathrm{mg} / \mathrm{ml})$ and purified enzyme from Virgibacillus halodenitrificans RSK CAS1, whereas, it took 20 min when only the enzyme was used (Ramamoorthy et al. 2014). Thus, our results clearly indicate that the addition of enzyme to a commercial detergent would enhance the performance of the detergent significantly in the process of removing blood stains and could possibly be used in the manufacture of cleaning detergent at the industrial scale.

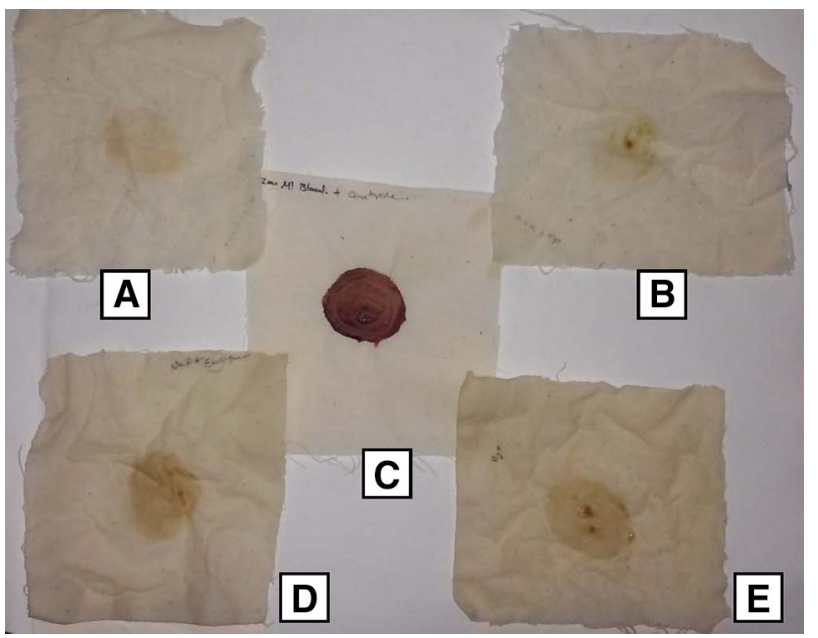

Fig. 5 Application of purified protease of Bacillus caseinilyticus on blood stain removal. A Cloth washed with protease $(2 \mathrm{ml})$ plus surf excel detergent $(5 \mathrm{mg} / \mathrm{ml}), B$ cloth washed with surf excel detergent $(5 \mathrm{mg} / \mathrm{ml}$ ) alone, $C$ control cloth with blood stain $D$ cloth washed with protease $(2 \mathrm{ml})$ alone, $E$ cloth washed with sterile distilled water

\section{Conclusion}

The enzyme (alkaline serine protease) produced by Bacillus caseinilyticus was purified using ammonium sulphate precipitation method $(60 \%)$, dialysis and finally with DEAE cellulose column chromatography. The purified protein has a molecular weight of $66 \mathrm{kDa}$. PMSF completely inhibited the alkaline protease activity indicating it as a serine protease. The purified enzyme showed its activity and stability at high temperatures and $\mathrm{pH}$ range. The enzyme also showed its varied stability in the presence of different inhibitors, metal ions, surfactants, oxidizing agent, polar, non polar solvents and had the capacity of hydrolyzing different substrates indicating the possibility of commercial exploitation of the alkaline serine protease in the laundry detergent industry.

Acknowledgments MT and SVR thank Department of Science and Technology, Government of India, for providing FTSYS project grants (SB/FT/LS-320/2012 and SB/FT/LS-115/2012, respectively).

\section{Compliance with ethical standards}

Conflict of interest The authors declare that there is no conflict of interest on publication of this article.

Open Access This article is distributed under the terms of the Creative Commons Attribution 4.0 International License (http:// creativecommons.org/licenses/by/4.0/), which permits unrestricted use, distribution, and reproduction in any medium, provided you give appropriate credit to the original author(s) and the source, provide a link to the Creative Commons license, and indicate if changes were made. 


\section{References}

Adinarayana K, Ellaiah P, Prasad DS (2003) Purification and partial characterization of thermostable serine alkaline protease from a newly isolated Bacillus subtilis PE-11. AAPS Pharma Sci Technician 4:56-63

Agarwal D, Patidar P, Banerjee T, Pati S (2004) Production of alkaline protease by Penicillium sp. under SSF conditions and its application to soy protein hydrolysis. Process Biochem 3:977-982

Annamalai N, Rajeswari MV, Thavasi R, Vijayalakshmi S, Balasubramanian $\mathrm{T}$ (2013) Optimization, purification and characterization of novel thermostable, haloalkaline, solvent stable protease from Bacillus halodurans CAS6 using marine shellfish wastes: a potential additive for detergent and antioxidant synthesis. Bioprocess Biosys Engg 36:873-883

Banerjee UC, Sani RK, Azmi W, Soni R (1999) Thermostable alkaline protease from Bacillus brevis and its characterization as a laundry detergent additive. Process Biochem 35:213-219

Banik RM, Prakash M (2004) Laundry detergent compatibility of the alkaline protease from Bacillus cereus. Microbiol Res 159:135-140

Cha M, Park JR, Yoon KN (2005) Purification and characterization of an alkaline serine protease producing angiotensin I-converting enzyme inhibitory peptide from Bacillus sp. SS103. J Med Food $8: 462-468$

Chase T Jr, Shaw E (1969) Comparison of esterase activities of trypsin, plasmin and thrombin of guanidinobenzoate esters. Titration of the enzymes. Biochem 8:2212-2224

Cheng K, Lu FP, Li M, Liu LL, Liang XM (2010) Purification and biochemical characterization of a serine alkaline protease TC4 from a new isolated Bacillus alcalophilus TCCC11004 in detergent formulations. Afr J Biotechnol 9:4942-4953

Dubey VK, Shah A, Jagannadham MV, Kayastha AM (2006) Effect of organic solvents on the molten globule state of procerain: $\beta$ sheet to $\alpha$-helix switchover in presence of trifluoroethanol. Protein Peptide Lett 13:545-547

Farhadian S, Asoodeh A, Lagzian M (2015) Purification, biochemical characterization and structural modeling of a potential htrA-like serine protease from Bacillus subtilis DR8806. J Mol Catylisis B Enzymatic. doi:10.1016/j.molcatb.2015.02.001

Geethanjali S, Subash A (2011) Optimisation of protease production by Bacillus subtilis isolated from mid gut of fresh water fish Labeorohita. World J Fish Mar Sci 3:88-95

Giri SS, Sukumaran V, Sen SS, Oviya M, Banu BN, Jena PK (2011) Purification and partial characterization of a detergent and oxidizing agent stable alkaline protease from a newly isolated Bacillus subtilis VSG-4 of tropical soil. J Microbiol 49:455-461

Gupta R, Beg QK, Lorenz P (2002) Bacterial alkaline proteases: molecular approaches and industrial applications. Appl Biochem Biotechnol 59:15-32

Gupta A, Roy I, Patel RK, Singh SP, Kahre SK, Gupta MN (2005) One-step purification and characterization of an alkaline protease from haloalkaliphilic Bacillus sp. J Chroma A 1-2:103-108

Hadder A, Agrebi R, Bougatef A, Himidet N, Sellami-Kamoun A, Nasri M (2009) Two detergent stable alkaline serine-proteases from Bacillus mojavensis A21: purification, characterization and potential application as a laundry detergent additive. Bioresour Technol 100(13):3366-3373

Horikoshi K (1999) Alkaliphiles: some applications of their products for biotechnology. Microbiol Mol Biol Rev 63(4):735-750

Huang Q, Peng Y, Li X, Wang H, Zhang Y (2003) Purification and characterization of an extracellular alkaline serine protease with dehairing function from Bacillus pumilus. Curr Microbiol 46:169-173
Ibrahim KS, Muniyandi J, Karutha Pandian S (2011) Purification and characterization of a manganese dependent alkaline serine protease from Bacillus pumilus TMS55. J Microbiol Biotechnol 21:20-27

Jacobs I, Eiasson M, Uhlen M, Flock JI (1985) Cloning, sequencing and expression of subtilisin Carlsberg from Bacillus licheniformis. Nucleic Acid Res 13(24):8913-8926

Jain D, Pancha I, Mishra SK, Shrivastav A, Mishra S (2012) Purification and characterization of haloalkaline thermoactive, solvent stable and SDS-induced protease from Bacillus sp.: a potential additive for laundry detergents. Bioresour Technol 115:228-236

Jaouadi B, Ellouz-Chaabouni S, Rhimi M, Bejar S (2008) Biochemical and molecular characterization of a detergent-stable serine alkaline protease from Bacillus pumilus CBS with high catalytic efficiency. Biochimie 90:1291-1305

Joo HS, Kumar CG, Park GC, Paik SR, Chang CS (2003) Oxidant and SDS-stable alkaline protease from Bacillus clausii I-52: production and some properties. J Appl Microbiol 95:267-272

Laemmli UK (1970) Cleavage of structural proteins during the assembly of the head of bacteriophage T4. Nature 227(5259):680-685

Lin Y, Means GE, Feeney RE (1969) The action of proteolytic enzymes on $N, N$ dimethyl proteins. J Biol Chem 244:789-793

Lowry OH, Rosebrough NJ, Farr AL, Randall RL (1951) Protein measurement with Folin phenol reagent. J Biol Chem 193:265-273

Mane R, Bapat M (2001) A study of extracellular alkaline protease from Bacillus subtilis NCIM 2713. Indian J Exp Biol 39:578-583

Moradian F, Khajeh K, Naderi-Manesh H, Ahmadvand R, Sajedi RH, Sadeghizadeh M (2006) Thiol-dependent serine alkaline proteases from sp. HR-08 and KR-8102: isolation, production, and characterization. Appl Biochem Biotechnol 134:77-87

Neelamegam A, Rajeswari MV, Sahu SK, Balasubramanian T (2014) Purification and characterization of solvent stable, alkaline protease from Bacillus firmus CAS 7 by microbial conversion of marine wastes and molecular mechanism underlying solvent stability. Process Biochem 49:1012-1019

Priya JD, Divakar K, Prabha MS, Selvam GP, Gautam P (2014) Isolation, purification and characterisation of an organic solventtolerant $\mathrm{Ca}^{2+}$-dependent protease from Bacillus megaterium AU02. Appl Biochem Biotechnol 172:910-932

Rahman RN, Mahamad S, Salleh AB, Basri M (2007) A new organic solvent tolerant protease from Bacillus pumilus $115 \mathrm{~b}$. J Ind Microbiol Biotechnol 34:509-517

Rai SK, Mukherjee AK (2010) Statistical optimization of production, purification and industrial application of a laundry detergent and organic solvent-stable subtilisin-like serine protease (Alzwiprase) from Bacillus subtilis DM-04. Biochem Eng J 48:173-180

Rajkumar R, Jayappriyan KR, Rengasamy R (2011) Purification and characterization of a protease produced by Bacillus megaterium RRM2: application in detergent and dehairing industries. J Basic Microbiol 51:614-624

Ramamoorthy S, Gnanakkan A, Chelladurai R (2014) Production and characterization of haloalkaline protease from ascidian-associated Virgibacillus halodenitrificans RSK CAS1 using marine wastes. Ann Microbiol. doi:10.1007/s13213-014-0987-8

Rao MB, Tanksale AM, Ghatge MS, Deshpande VV (1998) Molecular and biotechnological aspects of microbial proteases. Microbiol Mol Biol Rev 62(3):597-635

Raval VH, Pillai S, Rawal CM, Singh SP (2014) Biochemical and structural characterization of a detergent-stable serine alkaline protease from seawater haloalkaliphilic bacteria. Process Biochem 49:955-962 
Reddy LVA, Wee YJ, Ryu HW (2008) Purification and characterization of an organic solvent and detergent-tolerant novel protease produced by Bacillus sp. RKY3. J Chemi Technol Biotechnol 83:1526-1533

Sellami-Kamoun A, Haddar A, Ali NE, Ghorbel-Frikha B, Kanoun S, Nasri M (2008) Stability of thermostable alkaline protease from Bacillus licheniformis RP1 in commercial solid laundry detergent formulations. Microbiol Res 163(3):299-306

Shah K, Mody K, Keshri J, Jha B (2010) Purification and characterization of a solvent, detergent and oxidizing agent tolerant protease from Bacillus cereus isolated from the Gulf of Khambhat. J Mol Catalysis B Enzymatic 67:85-91

Vishnuvardhan Reddy S, Thirumala M, Farooq MD (2015) Bacillus caseinilyticus sp. nov., a novel alkali and thermo tolerant bacterium isolated from a soda lake. Int J Syst Evol Microbiol. doi:10.1099/ijs.0.000275

Wang SL, Chao CH, Liang TW, Chen CC (2009) Purification and characterization of protease and chitinase from Bacillus cereus TKU006 and conversion of marine wastes by these enzymes. Mar Biotechnol (NY) 11:334-344

Wang J, Xu A, Wan Y, Li Q (2013) Purification and characterization of a new metallo-neutral protease for beer brewing from Bacillus amyloliquefaciens SYB-001. Appl Biochem Biotechnol 170:2021-2033

Wells JA, Ferrari E, Henner DJ, Estell DA, Chen EY (1983) Cloning, sequencing, and secretion of Bacillus amyloliquefaciens subtilisin in Bacillus subtilis. Nucleic Acid Res 11(22):7911-7925 